\title{
MULTI-VARIED REALITIES OF MALAY CULTURAL IDENTITIES IN POPULAR TV FICTION
}

\author{
Mohd Muzhafar Idrus ${ }^{1 *}$, Ruzy Suliza Hashim², Raihanah M. M³, Harison Mohd Sidek, \\ Hazleena Baharun ${ }^{5}$, Noor Saazai Mat Saad ${ }^{6}$, Yurni Emilia Abdul Hamid 7 , Suzanah \\ Selamat ${ }^{8}$ \\ ${ }^{1}$ Dr. Universiti Sains Islam Malaysia, MALAYSIA, muzhafar.idrus@gmail.com \\ ${ }^{2}$ Prof. Dr. Universiti Kebangaan Malaysia, MALAYSIA, ruzy@ukm.edu.my \\ ${ }^{3}$ Associate Prof. Dr. Universiti Kebangsaan Malaysia, MALAYSIA, raihanah@ukm.edu.my \\ ${ }^{4}$ Associate Prof. Dr. Universiti Sains Islam Malaysia, MALAYSIA, harison@usim.edu.my \\ ${ }^{5}$ Dr. Universiti Sains Islam Malaysia, MALAYSIA, hazleena@usim.edu.my \\ ${ }^{6}$ Dr. Universiti Sains Islam Malaysia, MALAYSIA, noorsaazai@usim.edu.my \\ ${ }^{7}$ Universiti Sains Islam Malaysia, MALAYSIA, yurniemilia@usim.edu.my \\ 8Universiti Sains Islam Malaysia, MALAYSIA, suzanah@usim.edu.my \\ ${ }^{*}$ Corresponding author
}

\begin{abstract}
This paper discusses readings on Malay cultural identities in Malaysian context. While previous research on Malay cultural identity has presented a broad understanding, this paper attempts to frame this discussion based on three perspectives- elite constructions, socio-cultural worldviews, and resistance to Malay world. By placing Malay cultural identities in relation to the Malaysian context, it explores the dynamics concerning what is distinctive and worthwhile about Malay cultural identities. In addition, this study forms some of the bases for a renewed understanding and interests on Malay cultural identities in light of the burgeoning industries of popular TV fiction.
\end{abstract}

Keywords: Popular culture, postcolonial literature, Malayness, media, TV fiction

\section{INTRODUCTION}

In what follows, readings on Malay cultural identities in light of popular TV fiction proliferation, beginning from what is termed as earliest attempts are provided. The use of "attempts," we must nevertheless concede at the outset, does not reflect a definitive spectrum of works on Malay cultural identities but represent some of the many current readings relevant to bring to light what it means discussing Malay cultural subjectivities post-popular TV fiction era. These readings are then pieced together with those formed by socio-cultural worldviews and alternative perspectives of Malayness. By understanding these threads of inquiry, different concerns on Malay cultural studies and popular culture are tied. 


\section{MALAY CULTURAL IDENTITIES: ELITE CONSTRUCTIONS AND SOCIO- CULTURAL WORLDVIEWS}

The nature, shape, contours, and readings on Malay cultural identities are undeniably complex, and a comprehensive review of Malay cultural subjectivities is, however, beyond the dimension of this paper. Nevertheless, we can present some insights that may contribute to our brief understanding of Malayness. Some earliest and current attempts at defining, elaborating, and resisting Malay cultural identities could point to varying levels of literature. Although far from being definitive, they are relevant in describing Malay cultural identities that include, but are not limited to, Bangsa Melayu, Bangsa Malaysia, Islam Hadhari, Melayu Baru, 1Malaysia and Civic Melayu (Maznah, 2011; Mohd Muzhafar, Ruzy, \& Raihanah, 2015a, 2015b, 2016a, 2016b; Shamsul, 2004). The nation-state then formulates Malay subjects as defined by constitution as those speaking the Malay language, whose religion is Islam and adherence is to the Malay adat. Two areas emerge out of this reading- differentiation and assimilation (Mohd Muzhafar, 2015). It is argued that while Malayness is defined through Islam Hadhari and constitution, it also brings differentiation, a reading that suggests a level which guarantees Malay cultural agency. It is also argued that Malayness is nuanced in such a way that it is created to preserve the notion of differentiation with the evidence of the New Economic Policy (NEP). On the one hand, the NEP is set up to uplift Malay subjects who are at socio-economically disadvantaged positions, helping them to expand their cultural and social realms. On the other hand, the NEP is understood as creating a notion of differentiation among Malays, as it creates two spectrums- the Malay elites and the less ideal Malays. Although Islam Hadhari and Constitution suggest readings of differentiation, other chants celebrate assimilation. Bangsa Melayu, Bangsa Malaysia, Melayu Baru, Civic Melayu, and 1Malaysia point to the multilayered identities irrespective of ethnicities. 1Malaysia is unique in such a way that it emphasizes localization, paving ways for glocalization, suggesting the plethora of ways that Malay subjects can move successfully between his or her personal constructs of Malayness and the larger (Malay) community.

The socio-cultural worldviews of Malay subjects, as demonstrated elsewhere in the growing body of literature has illustrated that Malay adat, whose beliefs and values are intertwined with Hinduism and Islam (see for instance Andaya, 2002; Milner, 2008), has its specific values, that include but are not limited to politeness, veiling, gender relations, subservience, followership, forgiveness, repentance, and derhaka (Milner, 2008, Mohd Muzhafar, 2015; Mohd Muzhafar, Ruzy, Raihanah, 2015a, 2015b). Derhaka (treason) is a relationship of hierarchy of sorts- between god and subjects, kings and their subjects, and parents and children. Resistance to derhaka has some serious repercussions. In TV fiction, the questions of living-in-harmony, alongside politeness and gender are vexed in that they result in tensions. In Adam \& Hawa, for instance, although Ain and Adam are caught in the same bed unlawfully, resulting in their forced marriage, Ain stays through the marriage appearing submissive notwithstanding the fact that she does not like Adam seeing other girls over the remaining course of marriage. Although one careful reading of this TV fiction renders submissiveness and secondary place of Malay women, another reading of this example also points to cohabitation among men and women which diverges from principles of Islam and that any confrontation or resistance against Islamic precepts (read: Adam's and Ain's forced Islamic marriage) will be avoided in order to ensure a harmonious lifestyle. However, arguments against earlier readings on Malay subjectivities have surfaced; being Muslims for some Malays may suggest the need to separate religion from Malay subjects (Dahlia, 2014; Maznah, 2011), articulating possible convergence of influences and cultures, including the formation of Civic Melayu.

\section{MALAY CULTURAL IDENTITIES: ALTERNATIVE READINGS AGAINST ELITE CONSTRUCTION AND SOCIO-CULTURAL WORLDVIEWS}

This section is devoted to readings concerning issues that repress religion, Malay adat, and elite constructions of Malayness. Their links to TV fiction are made as the interconnectedness of changing realities of Malayness are presented. This section follows the Sollor's (1986) framework on consent where he stresses, "consent languages stress our abilities as mature free agents and architects of our fates to choose our destinies" (6). Following this framework, these readings argue that alternative Malayness is characterized by subjects who are able to choose, behave, and live without any associations. By displaying some issues about alternative Malay cultural identities, it contextualizes some issues that stand in stark contrast against the "prescribed" Malay adat in TV fiction.

One of these alternative readings points to the concept of Civic Melayu. Civic Melayu, a thesis put forth by Maznah (2011), is undeniably relevant as it is a concept distinct to already endorsed ideals of Malayness. Civic Melayu, as theorized, is a sense of "being cultural in context, the other, contractual in purpose" (53). According to Maznah (2011), one way of looking at Civic Melayu is that it straddles "between an ethnic state and a civic nation" (53). This contention means that it values cultural diversity while maintaining a civic 
argumentation that views individuals as citizens irrespective of ethnicities. By positing Civic Melayu, it assumes that everybody is equal, suggesting greater resistance against Malay nationalism, or against "the maintenance of the continued British 'protection' of 'independent' Malay entities under which bangsa Melayu would progress" (Ariffin, 1993, p. 55-56). By taking an example of cultural diversity, Civic Melayu endorses the resistance against the exclusive nature of Malayness, moving away from a static and unitary differentiation.

That being said, there are substantial evidence to support and contextualize the emerging studies on Civic Melayu. These questions are more or less reflected in Dahlia's (2012) focus group interviews:

"As a Muslim, I disagree with the notion of special privileges for the Malays. It's purely on racially-drawn lines, and that's always a step backwards, not forwards... it doesn't encourage people to compete, to think (43)."

Although Dahlia's (2012) study remains questionable in terms of its sampling and generalization, the study has uncovered readings alternative to our conscious understanding of Malayness. What the findings foretell is that some Malays have vaunted to distance Malayness from the broad spectrums of religion and ethnicity, calling for a different understanding of Malay cultural subjectivities. Such attachments to ethnicity and religion may suggest the necessity to divorce Malayness from the rigidity of hegemony and authoritative governance, raising the question, how do we go about extending this concept of Malayness to broader, existing literature? As Muhammad Ikmal (1996) has long observed, these argumentations on resisting previous Malayness and perhaps embracing Civic Melayu are, in fact, indications of convergence of cultures. Milner's (2008) line of questioning is also useful here; he asks, "Would there be some way of integrating the different adat and how would one then refer to the "Malays" and the other constituent elements?" (p.214). This means that the project in challenging currently prescribed notion of Malayness may involve cosmopolitanism and Western influences, in light of globalization (Maznah, 2011).

On broader terms, this process of destabilizing such constructs of Malay may mean the separation between state and religion, and that religious issues (would) probably become somewhat less important (Kahn, 2006a, 2006b; Milner, 2008). Moreover, Ramli (2014) argues that subjectivities distinct in the works of arts should be unveiled for the purpose of understanding alternative cultural identities. Although critics aver that not all Malays today embrace alternative Malayness or Civic Melayu, they have a place in the larger social Malay practices where they reify the kinds of social changes concerning Malayness on TV fiction. Such process of destabilizing Malayness which is shown in previous research (see for instance Mohd Muzhafar, Ruzy \& Raihanah, 2014) also suggests the proliferation of varying social and cultural issues (Abdul Rahman Embong, 2013). In TV fiction, some Malays live without the constraints of Islam and adat, by engaging specifically with the demands modernism makes on mainstream perceptions of Malay cultural identities.

Thus, while perhaps some may dismantle the term, alternative Malays, one must challenge the current and endorsed preconceived ideas of Malay-Muslims, especially when such instances are repeatedly shown in popular TV fiction. Rather than solely understanding Malay-Muslim character as representative of Malay subjects in Malaysia, this link between what we know of Malay cultural identities to what is enacted in practice may involve translating the self onto the present context of Malaysia. Thus, in TV fiction, while the accumulation of scenes on issues of hanging out in bars, wallowing in alcohol, or getting drunk shows this paradox, it is our point that the process of understanding cultural identities should consider acknowledging these deviant acts as constantly recurring.

\section{CONCLUSION}

Firstly, from the perspectives of elite constructions, Malay subjectivities can be defined by two principlesdifferentiation and assimilation. While differentiation aims at centralizing Malayness and Islam, enhanced through Islam Hadhari, the constitution, and the NEP, assimilation, although not coerced, permits the plethora of ways Malay subjects can move (un)successfully between his or her personal constructs of Malayness and the larger (Malay) community. Propelled by the ideas of Bangsa Melayu, Bangsa Malaysia, Melayu Baru, and 1Malaysia, assimilation weaves the multi-faceted realities of Malay subjectivities. Secondly, from the socio-cultural perspectives, we see Malayness's relationship with adat, intersecting major characteristics, beliefs, and values that include but are not limited to politeness, veiling, gender, subservience, forgiveness, and repentance. Thirdly, however, some Malays are read as fleeing from the constraints of ethnicities, religion, and parental intervention, who do not view, abscribe, identify, or embrace such adat-Islamic impositions. Putting it differently, such shifts of moving away from familiar adat-Islamic values maintain that the questions of state and religion be treated separately so that they oppose the singly and unitary cocoon of Malay cultural identity, establishing some alternative readings of Malay cultural 
IJASOS- International E-Journal of Advances in Social Sciences, Vol.II, Issue 6, December 2016

identities such as Civic Melayu. Through these readings, we are able to bridge what we know thus far about Malay cultural identities and the many ways these are translated on popular TV fiction in Malaysia.

\section{REFERENCE LIST}

Abdul Rahman E. (2013). Making sense of emerging social realities: new agenda for Malaysian social science. Public Lecture. Lecture conducted in Universiti Kebangsaan Malaysia, Bangi, Malaysia, 12 April 2013.

Andaya, L. Y. (2002). Orang Asli and the Melayu in the history of the Malay peninsula. Journal of Malayan Bureau of Royal Asiatic Society, 75(1), 23-48.

Ariffin, O. (1993). Bangsa Melayu: Malay concepts of democracy and community 1945-1950. Kuala Lumpur: Oxford University Press.

Dahlia, M. (2012). Redefining "Malayness:" expectations of young-adult Malaysian Muslims. In Hopkins, J. \& Lee, J. C. H. (Eds.), Thinking through Malaysia: culture and identity in the 21st century (pp. 31-50). Petaling Jaya: Strategic Information and Research Development Center.

Dahlia, M. (2014). Gender, Malayness, and the ummah: cultural consumption and Malay-Muslim identity. Asian Studies Review, 38(3), 403-421.

Kahn, J. (2006a). Other Malays: nationalism and cosmopolitan in the modern Malay world. Singapore: Singapore University Press.

Kahn, J. S. (2006b). The making and unmaking (?) of a Malay race. Social Analysis, 49(2), 164-172.

Ramli Ibrahim. (2014). PADU-KITA Merdeka Symposium. Public lecture. Lecture conducted in Universiti Kebangsaan Malaysia, Bangi, Malaysia, 16 August 2014.

Maznah M. (2011). Malaysia: contending imaginations of Malayness. In Maznah, M. \& Aljunied, S. M. K. (Eds.), Melayu: the politics, poetics and paradoxes of Malayness (pp. 34-67). Singapore: National University Press.

Milner, A. (2008). The Malays. United Kingdom. Wiley-Blackwell.

Mohd Muzhafar, I. (2015). The unconscious Malay psyche: A multidisciplinary study of cultural identities in selected popular Malaysian television fiction. (Unpublished doctoral dissertation). Universiti Kebangsaan Malaysia, Bangi, Malaysia.

Mohd Muzhafar, I., Ruzy Suliza Hashim \& Raihanah M. M. (2014). Imagining alternative modernities: negotiating Islamic-ness and Malay-ness on popular TV fiction. Asian Economic and Social Review, 4(12), 1798-1811.

Mohd Muzhafar, I., Ruzy Suliza Hashim, \& Raihanah M. M. (2015a). Malay cultural identities: A review. Humanities and Social Sciences Letters. 3(1), 1-9. http://www.pakinsight.com/pdffiles/HSSL-20153(1)-1-9.pdf.

Mohd Muzhafar, I., Ruzy Suliza Hashim, \& Raihanah M. M. (2015b). Followership: Boosting power and position in popular TV Fiction. GEMA Online Journal of Language Studies. 15(1), 207-224. http://ejournal.ukm.my/gema/article/view/5977/3159.

Mohd Muzhafar, I., Ruzy Suliza Hashim, \& Raihanah M. M. (2016a). Re-discovery of the Malay 'local:' Youth and TV fiction in Malaysia. International Journal of Adolescence and Youth, 1-16. doi: 10.1080/02673843.2016.1154876.

Mohd Muzhafar, I., Ruzy Suliza Hashim, \& Raihanah M. M. (2016b). Globalization, Re-Discovery of the Malay 'Local,' and Popular TV fiction through audience narratives. 3L: The Southeast Asian Journal of English Language Studies, 22(3), 31-48. http://ejournals.ukm.my/3l/article/view/11107/4375.

Muhammad Ikmal, S. (1996). Malay nationalism and national identity. In Muhammad Ikmal and Zahid Emby. (Eds.), Malaysia: Critical perspectives (pp.34-73). Petaling Jaya: Persatuan Sains Sosial Malaysia.

Shamsul Amri, B. (2004). History of identity, an identity of a history: the idea and practice of "Malayness" in Malaysia reconsidered. In Barnard, T. (Ed.), Contesting Malayness: Malay identity across boundaries (pp. 135-148). Singapore: Singapore University Press.

Sollors, W. (1986). Beyond ethnicity: consent and descent in American culture. New York: Oxford University Press. 